\title{
Trophic positions of three euphausiid species from the Prince Edward Islands (Southern Ocean): implications for the pelagic food web structure
}

\author{
L. J. Gurney ${ }^{1, *}$, P. W. Froneman ${ }^{1}$, E. A. Pakhomov ${ }^{1,2}$, C. D. McQuaid ${ }^{1}$ \\ ${ }^{1}$ Southern Ocean Group, Department of Zoology and Entomology, Rhodes University, PO Box 94, Grahamstown 6140, \\ South Africa \\ ${ }^{2}$ Department of Zoology, University of Fort Hare, P/Bag X1314, Alice 5700, South Africa
}

\begin{abstract}
The relative trophic positions of Euphausia vallentini (juveniles and adults), E. longirostris (adults) and Nematoscelis megalops (adults) were investigated using samples collected in the vicinity of the Prince Edward archipelago during austral autumn (April/May) of 1998 on voyage 87 of the MV 'SA Agulhas'. Gut content analysis and stable nitrogen isotope measurements $\left(\delta^{15} \mathrm{~N}\right)$ were performed on the same individuals. For comparative purposes, nitrogen isotope ratios of the copepod Calanus simillimis, the hyperid amphipod Themisto gaudichaudi and the fish Ceratoscopelus warmingi were also analysed. The results of the gut content analysis for E. vallentini juveniles showed that there was a high contribution of phytoplankton to the diet. Stable nitrogen isotope analysis supported this and indicated that $E$. vallentini juveniles occupied a similar trophic position to that of the copepod (mean $\delta^{15} \mathrm{~N}$ values of 2.38 and $1.72 \%$ respectively). E. vallentini adults were found to be omnivorous, but the contribution of carnivory to the diet was difficult to determine. High phytoplankton and low mesozooplankton contributions to the diet from the gut content analysis suggested a predominantly herbivorous diet. However, the stable nitrogen isotope results showed that $E$. vallentini adults were closely grouped with $T$. gaudichaudi (mean $\delta^{15} \mathrm{~N}$ values of 3.66 and $4.13 \%$ respectively), indicating a high degree of omnivory and a relatively large heterotrophic contribution to the diet. Irrespective of the degree of carnivory, a dietary shift with an increase in size was evident for this species. The gut content analysis of E. longirostris showed that this species consumed large amounts of both phytoplankton and metazoan prey. However, the stable nitrogen isotope analysis indicated a high degree of carnivory (mean $\delta^{15} \mathrm{~N}=6.88 \%$ ). Although the gut content analysis showed that $N$. megalops had a lower contribution of mesozooplankton to the diet compared to that of $E$. longirostris, the stable isotope analysis showed that these 2 species occupied a similar position ( $N$. megalops mean $\delta^{15} \mathrm{~N}=6.83 \%$ ). The findings of this study support findings in the literature and show that $E$. vallentini juveniles are herbivorous and $N$. megalops adults are carnivorous. However, adults of $E$. vallentini and E. longirostris appear to have higher contributions of heterotrophic carbon to their diets than has been assumed and may occupy higher trophic positions than initially predicted.
\end{abstract}

KEY WORDS: Sub-Antarctic euphausiids $\cdot$ Feeding ecology $\cdot$ Diet $\cdot$ Stable isotopes $\cdot$ Prince Edward Islands

\section{INTRODUCTION}

Euphausiids are generally considered to be opportunistic omnivores and may adjust their feeding strategy according to ambient food availability (Mauchline

*E-mail: leighgurney@hotmail.com
1980). Therefore, accurately assessing the trophic positions of these organisms is often difficult as feeding strategies will adapt according to changes in food composition. Generally, the trophic position of an organism is assessed using stomach content analysis (e.g. Hopkins 1985, Hopkins \& Torres 1989). There are, however, several limitations associated with employing gut 
content analysis for determining trophic position. Firstly, it is difficult to provide quantitative results. For instance, euphausiids have been observed to pierce open the carapace of their crustacean prey and suck out the body contents (Mauchline 1980). On these occasions the origin of amorphous material in the stomach cannot be determined. Secondly, elements with hard frustules (for example, diatoms) may be over represented in the stomach contents, while soft bodied items ingested may be easily digested and therefore under-represented in the analysis. Thirdly, each analysis only represents one moment in time, and therefore many individuals must be analysed if an accurate estimation of the diet of a species is to be assessed. This is both labour intensive and time consuming.

An alternative method for investigating trophic positions has been developed using stable isotopes. Nitrogen occurs naturally as 2 isotopes, ${ }^{14} \mathrm{~N}$ and ${ }^{15} \mathrm{~N}$. Fractionation between ${ }^{14} \mathrm{~N}$ and ${ }^{15} \mathrm{~N}$ occurs during food assimilation as the lighter isotope is metabolised more readily and preferentially excreted as a by-product of protein synthesis, leaving the animal enriched in ${ }^{15} \mathrm{~N}$ relative to its diet (Dunton et al. 1989, Kling et al. 1992, Holmes 1996). As this effect is cumulative, stable nitrogen isotope ratios $\left(\delta^{15} \mathrm{~N}\right)$ can be used to identify trophic position (Minagawa \& Wada 1984, Dunton et al. 1989, Sugisaki et al. 1991, Wada et al. 1991, Kling et al. 1992, Hobson 1993, Thomas \& Cahoon 1993, Gu et al. 1994, Hobson \& Welch 1995, Jennings et al. 1997). Minagawa \& Wada (1984) reported an average stepwise increase of $3.4 \pm 1.1 \%$ o $\delta^{15} \mathrm{~N}$ between trophic levels across a wide range of habitats including terrestrial, freshwater and marine. The strength of stable-isotope analysis is that it is an accurate time-integrated measure of food assimilation or feeding history of an individual organism (Kling et al. 1992, Hobson 1993). The time period reflected by the isotopic analysis is determined by the turnover rate of the proteins in the tissue examined (Tieszen et al. 1983).

The 3 larger euphausiids species found in the vicinity of the Prince Edward Islands were selected for this study, namely Euphausia vallentini, E. longirostris and Nematoscelis megalops. Investigations of the diet of $E$. vallentini have shown this species to be principally herbivorous (Mauchline \& Fisher 1969). E. longirostris is the largest of the 3 euphausiids, and no feeding studies are available for this species in the literature, although the feeding basket of this species suggests that it attains its food from filter feeding (Mauchline 1980). Mouthparts in species of the genus Nematoscelis are generally less setose than the 2 Euphausia spp. and are not well adapted to filter feeding (Mauchline 1967, Mauchline \& Fisher 1969). The second pair of thoracic limbs in $N$. megalops is greatly elongated, and associated with this modification is the division of the eyes into 2 lobes (Mauchline 1980). These 2 modifications are thought to be adaptations to a more carnivorous feeding habit, although this is as yet unproven (Mauchline 1980). For this study the trophic positions of 3 euphausiids, E. vallentini, E. longirostris and N. megalops collected in the vicinity of the Prince Edward Islands were assessed using both gut content analysis and stable nitrogen isotopes.

\section{MATERIALS AND METHODS}

Samples were taken during austral autumn (April/ May) of 1998 aboard the MV 'SA Agulhas' (Voyages 87) in the vicinity of the Prince Edward Archipelago (Fig. 1). Specimens were collected using a $300 \mathrm{~mm}$ mesh Bongo net $\left(0.25 \mathrm{~m}^{-2}\right.$ mouth area) and were preserved in 4 to $6 \%$ buffered formaldehyde. Identifications were made using a dissecting microscope operated at $25 \times$ magnification using the works of Baker et al. (1990) and Kirkwood (1982). Ten adult specimens of each species were randomly selected from samples collected during a $24 \mathrm{~h}$ station (MS3-33, MS3-34 and MS3-36) in 1998 and in addition, 10 Euphausia vallentini adults and $10 \mathrm{E}$. vallentini juveniles were selected from an ad hoc tow, Stn Box 3, from the same year (Table 1). As no attempt was made to assess the sex or maturity of the euphausiids, E. vallentini juveniles were considered to be individuals $<15 \mathrm{~mm}$ in length (Mauchline \& Fisher 1969).

Gut content analysis. The stomachs of the euphausiids were carefully dissected out and stomach fullness was estimated visually. The stomach contents were

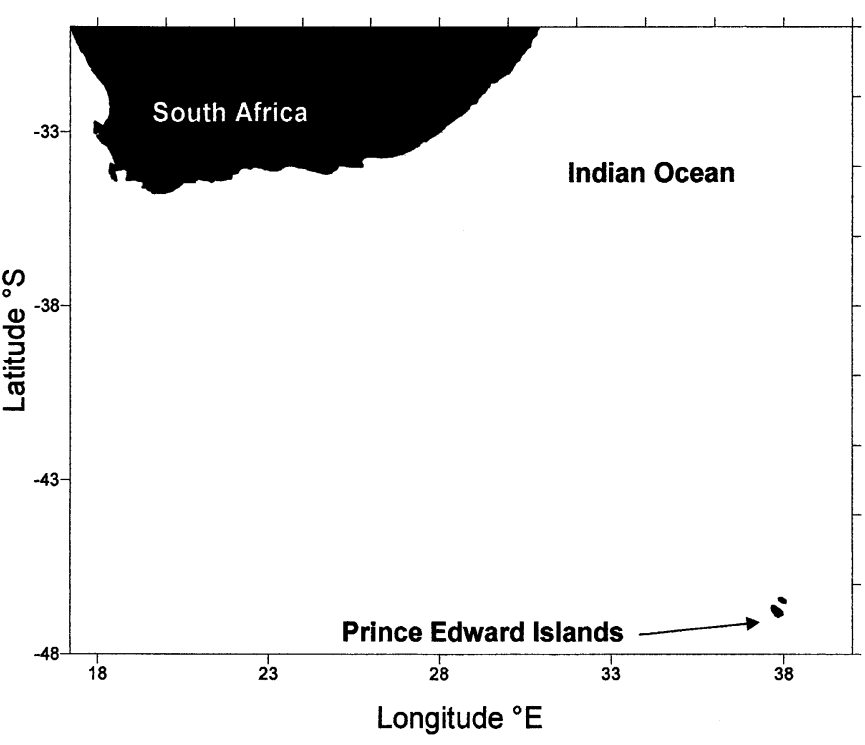

Fig. 1. Map showing location of the Prince Edward Islands 
Table 1. List of species, station number, sampling position, date and sampling depth. $\mathrm{A}=$ adult; $\mathrm{J}=$ juvenile; $1=\mathrm{Box} 3 \mathrm{Stn}$; $2=$ MS3-36 Stn

\begin{tabular}{|c|c|c|c|c|c|}
\hline Species & Stn & Latitude (S) & Longitude (E) & Date & Sampling depth (m) \\
\hline Calanus simillimus & MS3-34 & $46^{\circ} 45.05$ & $38^{\circ} 20.20$ & 22 Apr 1998 & $0-201$ \\
\hline Euphausia vallentini (J) & Box 3 & $46^{\circ} 58.76$ & $37^{\circ} 56.64$ & 12 Apr 1998 & $0-161$ \\
\hline Euphausia vallentini 1 (A) & Box 3 & $46^{\circ} 58.76$ & $37^{\circ} 56.64$ & 12 Apr 1998 & $0-161$ \\
\hline Euphausia vallentini 2 (A) & MS3-36 & $46^{\circ} 45.86$ & $38^{\circ} 18.21$ & 22 Apr 1998 & $0-200$ \\
\hline Themisto gaudichaudi & MS3-33/-34/-36 & $\begin{array}{l}46^{\circ} 49.25 \\
46^{\circ} 45.05 \\
46^{\circ} 45.86\end{array}$ & $\begin{array}{l}38^{\circ} 16.70 \\
38^{\circ} 20.20 \\
38^{\circ} 18.21\end{array}$ & 21/22 Apr 1998 & $0-200$ \\
\hline Euphausia longirostris & MS3-33/-34/-36 & $\begin{array}{l}46^{\circ} 49.25 \\
46^{\circ} 45.05 \\
46^{\circ} 45.86\end{array}$ & $\begin{array}{l}38^{\circ} 16.70 \\
38^{\circ} 20.20 \\
38^{\circ} 18.21\end{array}$ & 21/22 Apr 1998 & $0-200$ \\
\hline Nematoscelis megalops & MS3-36 & $46^{\circ} 45.86$ & $38^{\circ} 18.21$ & 22 Apr 1998 & $0-200$ \\
\hline Ceratoscopelus warmingi & A15917 & $41^{\circ} 14.07$ & $02^{\circ} 45.70$ & 3 Mar 1994 & $0-50$ \\
\hline
\end{tabular}

then emptied into a cavity slide, mixed as evenly as possible and allowed time to settle (Hopkins \& Torres 1989, Hopkins et al. 1993). Individual food items were identified and counted using an inverted microscope operated at 200 to $400 \times$ magnification. Where possible, items were identified to species level, using the works of Priddle \& Fryxell (1985), Boden \& Reid (1989) and Tomas (1996). In samples where there was a high density of items, all objects in every fifth field of view were counted until 500 or more objects had been counted. In samples where sub-sampling occurred, the whole sample was inspected for large items (e.g. whole copepod carapaces). In many cases the entire sample was considered (29/50 of the samples). The data are presented as percentage composition by number $(\% \mathrm{~N})$ and percentage occurrence $(\% \mathrm{O})$. Percentage composition by number represents the proportion of a particular item relative to the total number of all items counted in the stomach and provides information on each individual's feeding behaviour. Percentage occurrence provides information on the proportion of stomachs containing a particular prey item, irrespective of the amount and reflects the uniformity with which a particular prey item is selected by a group of specimens (Tirasin \& Jørgensen 1999).

Stable nitrogen isotopes. Stable nitrogen isotope analysis was carried out on the same euphausiid individuals that were used for the gut content analysis. In addition to these specimens, the copepod Calanus simillimus and the hyperiid amphipod Themisto gaudichaudi were selected from the same samples as the euphausiids. Ceratoscopelus warmingi, a small planktivorous fish, was sampled aboard the RV 'Africana' in March 1994 in the vicinity of the Prince Edward Islands (Stn A15917-119). These additional species were cho- sen to form a framework of species with known dietary habits within which the euphausiids could be placed. Samples were stored for 6 mo before analysis. $C$. warmingi were initially preserved in formalin and later transferred to $70 \%$ alcohol. All samples were rinsed and then submerged in distilled water for $6 \mathrm{~h}$ to leach remaining preservative from the specimens (Mullin et al. 1984). Stomachs were removed from all specimens with the exception of $C$. simillimus, for which the removal of the stomachs was not possible due to their small size. All samples were dried at $60^{\circ} \mathrm{C}$ for $48 \mathrm{~h}$. Individual animals were weighed using a Sartorius microbalance and then manually pulverised using a mortar and pestle. Twenty $C$. simillimus specimens were pooled for each sample. Muscle tissue was dissected from the fish for analysis. Subsamples of between 0.6 and $0.7 \mathrm{mg}$ were weighed out for nitrogen isotope analysis. Ten replicate individuals were analysed for each species, with the exception of Euphausia longirostris $(\mathrm{n}=8)$. Replication was also performed on individual specimens using between 2 and 5 subsamples. Measurements of stable nitrogen isotope ratios were made using an automated elemental analyzer coupled to an isotope ratio dual inlet mass spectrometer (Finnigan MAT 252). Two internal standards (Merck gelatine and Valine) were analysed after every tenth sample for calibration of the mass spectrometer. Stable nitrogen isotope ratios were expressed as parts per thousand (\%o) according to the following relationship:

$$
\delta^{15} \mathrm{~N}=\left[\left(R_{\text {sample }} / R_{\text {standard }}\right)-1\right] \times 10^{3}
$$

where $R$ is the corresponding ${ }^{15} \mathrm{~N} /{ }^{14} \mathrm{~N}$ ratio. The standard for nitrogen is atmospheric $\mathrm{N}_{2}$ (air), which is assigned an arbitrary $\delta^{15} \mathrm{~N}$ value of $0 \%$ (Holmes 1996). 
ANOVA was used to determine whether there were significant differences between groups for the dry weight and the nitrogen isotope data. A NewmanKeuls multiple range test was used to identify group interactions (Zar 1984).

\section{RESULTS}

\section{Gut content analysis}

Results of gut content analysis are shown in Table 2. Euphausia vallentini adults and juveniles had similar phytoplankton contributions of between 37 and $42 \%$. E. longirostris and Nematoscelis megalops had similar phytoplankton contributions of 30 and $32 \%$ respectively. Of the diatoms identified in all stomachs analysed, Fragilariopsis spp. accounted for the highest percentage by number (over $85 \%$ ). The percentage occurrence was $100 \%$ for all groups, with the exception of N. megalops, where it occurred in $60 \%$ of stomachs examined. Although the percentage contribution of Thalassiosira spp. to all groups was relatively low, species from this genus were observed in all but 4 individuals. Other diatoms, including Dactyliosolen spp., Nitzschia spp., Navicula spp., Asteromphalus spp. and
Thalassionema spp. were observed but constituted less than $9 \%$ of all identified diatoms in the stomachs of all specimens analysed. Similar amounts of protoplankton were found in all groups, ranging from $7.0 \%$ in E. vallentini juveniles to $12.7 \%$ in $N$. megalops. N. megalops had the lowest percentage occurrence for tintinnids and silicoflagellates.

Euphausia vallentini adults (from both stations) and juveniles had low mesozooplankton contributions, ranging between 1.2 and $2.2 \%$ (Table 2). These low percentages did, however, include carapace fragments and appendages of crustaceans for all individuals. Ommatidia (usually the crystalline cones of crustacean compound eyes) were observed in 19 of the 30 specimens, and Limacina spp. shell fragments were only observed in 1 adult. E. longirostris had the highest mesozooplankton contribution $(23.4 \%)$, but this was largely attributable to the high contribution of Limacina spp. shell fragments. When shell fragments are excluded from the analysis, the mesozooplankton contribution dropped to $5.6 \%$ for this species. All individuals of $E$. longirostris had carapace fragments, and all but one had crustacean appendages. Mesozooplankton fragments comprised $12.7 \%$ of the items counted in the stomach contents of Nematoscelis megalops. A high percentage occurrence was ob-

Table 2. Stomach contents of the 5 groups of euphausiid analysed from samples collected in $1998, \mathrm{n}=10$ for each group; $\% \mathrm{~N}=$ percentage of items counted within a group; $\% \mathrm{O}=$ percentage occurrence within a group $\mathrm{J}=$ juveniles; $\mathrm{A}=$ adults

\begin{tabular}{|c|c|c|c|c|c|c|c|c|c|c|}
\hline \multirow[t]{2}{*}{$\begin{array}{l}\text { Species } \\
\text { Stn: }\end{array}$} & \multicolumn{2}{|c|}{$\begin{array}{l}\text { E. vallentini }(\mathrm{J}) \\
\text { Box } 3\end{array}$} & \multicolumn{2}{|c|}{$\begin{array}{l}\text { E. vallentini (A) } \\
\text { Box } 3\end{array}$} & \multicolumn{2}{|c|}{$\begin{array}{l}\text { E. vallentini (A) } \\
\text { MS3-36 }\end{array}$} & \multicolumn{2}{|c|}{$\begin{array}{l}\text { E. longirostris } \\
\text { MS3-33/34/36 }\end{array}$} & \multicolumn{2}{|c|}{$\begin{array}{c}\text { N. megalops } \\
\text { MS3-36 }\end{array}$} \\
\hline & $\% \mathrm{~N}$ & $\% \mathrm{O}$ & $\% \mathrm{~N}$ & $\% \mathrm{O}$ & $\% \mathrm{~N}$ & $\% \mathrm{O}$ & $\% \mathrm{~N}$ & $\% \mathrm{O}$ & $\% \mathrm{~N}$ & $\% \mathrm{O}$ \\
\hline Phytoplankton & 42.0 & & 37.4 & & 41.7 & & 30.5 & & 32.6 & \\
\hline Fragilariopsis spp. & 38.8 & 100 & 34.4 & 100 & 35.2 & 100 & 23.7 & 100 & 26.4 & 60 \\
\hline Thalassiosira spp. & 1.9 & 90 & 1.3 & 100 & 3.4 & 100 & 2.4 & 100 & 3.1 & 70 \\
\hline Diatoms $^{\mathrm{a}}$ & 1.3 & 80 & 1.8 & 100 & 3.2 & 90 & 4.4 & 90 & 3.1 & 30 \\
\hline Protoplankton & 7.0 & & 11.8 & & 9.5 & & 10.8 & & 12.7 & \\
\hline Dinoflagellates & 0.4 & 50 & 1.2 & 90 & 0.6 & 70 & 0.7 & 80 & 0.4 & 30 \\
\hline Dinoflagellate cysts & 0.3 & 40 & 1.5 & 100 & 1.2 & 50 & 1.5 & 100 & 1.0 & 20 \\
\hline Tintinnids & 0.6 & 60 & 1.2 & 90 & 3.0 & 90 & 2.4 & 100 & 3.5 & 30 \\
\hline Silica flagellates & 3.1 & 90 & 3.0 & 100 & 0.8 & 60 & 2.5 & 100 & 2.4 & 10 \\
\hline Ciliates & 0.0 & 0 & 0.0 & 0 & 0.0 & 0 & 0.3 & 40 & 0.0 & 0 \\
\hline Round bodies & 2.5 & 100 & 4.9 & 100 & 3.9 & 80 & 3.3 & 80 & 5.4 & 80 \\
\hline Mesozooplankton fragments & 1.3 & & 1.2 & & 2.2 & & 23.4 & & 12.7 & \\
\hline Carapace fragments & 0.4 & 100 & 0.2 & 100 & 1.2 & 100 & 1.5 & 100 & 5.4 & 90 \\
\hline Appendages & 0.4 & 100 & 0.4 & 100 & 0.6 & 100 & 2.9 & 90 & 6.6 & 90 \\
\hline Ommatidia & 0.5 & 60 & 0.5 & 100 & 0.4 & 30 & 1.2 & 80 & 0.7 & 10 \\
\hline Limacina shell fragments & 0.0 & 0 & $<0.1$ & 10 & 0.0 & 0 & 17.9 & 80 & 0.0 & 0 \\
\hline Setae & 30.7 & 100 & 34.6 & 100 & 25.2 & 100 & 18.7 & 100 & 17.7 & 50 \\
\hline Foraminiferans & 0.1 & 20 & 0.1 & 30 & 0.0 & 10 & 0.2 & 60 & 0.3 & 20 \\
\hline Other & 19.0 & & 15.0 & & 21.3 & & 16.6 & & 24.4 & \\
\hline Unidentifiable & 10.3 & 100 & 7.7 & 100 & 11.2 & 100 & 14.0 & 100 & 13.1 & 100 \\
\hline Bolus & 8.6 & 90 & 7.3 & 100 & 10.1 & 100 & 2.3 & 100 & 11.0 & 10 \\
\hline Items counted (total) & 1694 & & 4294 & & 2709 & & 6128 & & 1176 & \\
\hline
\end{tabular}


served for both carapace fragments and append-ages. Only 1 individual was found to have ommatidia, and no Limacina spp. shell fragments were found. The contribution of setae ranged from 18 to $35 \%$ (Table 2). The origin of this material could not be identified, and contribution to diet was therefore difficult to determine as the ingestion of 1 polychaete could produce hundreds of setae. The contribution of foraminiferans was low for all groups considered. The remaining gut material consisted of unidentifiable material and boluses of amorphous material found in all specimens and ranged from 15.0 to $24.4 \%$ in number, for all groups investigated.
Table 3. Results of Newman-Keuls multiple range tests for dry weight and stable nitrogen isotope ratios. $\mathrm{A}=$ adult; $\mathrm{J}=$ juvenile; $1=$ Box $3 \mathrm{Stn}$; $2=$ MS3-36 Stn

\begin{tabular}{|c|c|c|}
\hline Species & $\begin{array}{l}\text { Dry weight } \\
\text { Homogenous groups } \\
(\mathrm{p}<0.05)\end{array}$ & $\begin{array}{c}\delta^{15} \mathrm{~N} \\
\text { Homogenous groups } \\
(\mathrm{p}<0.05)\end{array}$ \\
\hline Calanus simillimus & $x$ & $x$ \\
\hline Euphausia vallentini (J) & $x$ & $\times$ \\
\hline Euphausia vallentini 1 (A) & $\times$ & $\times$ \\
\hline Euphausia vallentini 2 (A) & $x$ & $x$ \\
\hline Themisto gaudichaudi & $\times$ & $\times$ \\
\hline Euphausia longirostris & $\times$ & $\times$ \\
\hline Nematoscelis megalops & $\times$ & $x$ \\
\hline Ceratoscopelus warmingi & $x$ & $\times$ \\
\hline
\end{tabular}

\section{Stable nitrogen isotopes}

Nitrogen isotope ratios differed significantly between groups (Fig. 2, Table 3). As expected, the lowest $\delta^{15} \mathrm{~N}$ value was found in the herbivorous copepod Calanus simillimus (Fig. 2). Among the euphausiids, Euphausia vallentini juveniles had a low mean $\delta^{15} \mathrm{~N}$ value, slightly but significantly higher than C. simillimus, which suggests that they exhibit a largely herbivorous diet, supplemented by a minor heterotrophic component. E. vallentini adults from both stations had significantly higher $\delta^{15} \mathrm{~N}$ values than the juveniles. $E$. vallentini adults from the station 'Box 3' had slightly higher isotope ratios than those taken from the $24 \mathrm{~h}$ station, but the difference between them was not significant. E. vallentini adults from both stations were closely grouped with the hyperiid Themisto gau- dichaudi (Fig. 2). E. longirostris and Nematoscelis megalops had similar mean $\delta^{15} \mathrm{~N}$ values (6.88 and $6.83 \%$ respectively), $2.7 \%$ above the hyperiid. Finally the planktivorous fish Ceratoscopelus warmingi was found to have the highest $\delta^{15} \mathrm{~N}$ value of $9.55 \%$ (Table 3). Within sample replication had a standard deviation of between 0.12 and $0.41 \%$.

Based on dry weight, 4 size groups were identified from the multiple range analysis (ANOVA, $\mathrm{p}<0.05$; Newman-Keuls, p < 0.05) (Fig. 3). Calanus simillimus specimens and Euphausia vallentini juveniles were smallest in size and were not significantly different from each other ( $\mathrm{p}>0.05)$. E. vallentini adults from station 'Box 3' were slightly, but not significantly, larger than those collected from the $24 \mathrm{~h}$ station. E. vallentini adults from both stations, Themisto gaudichaudi and Nematoscelis megalops all grouped out together with

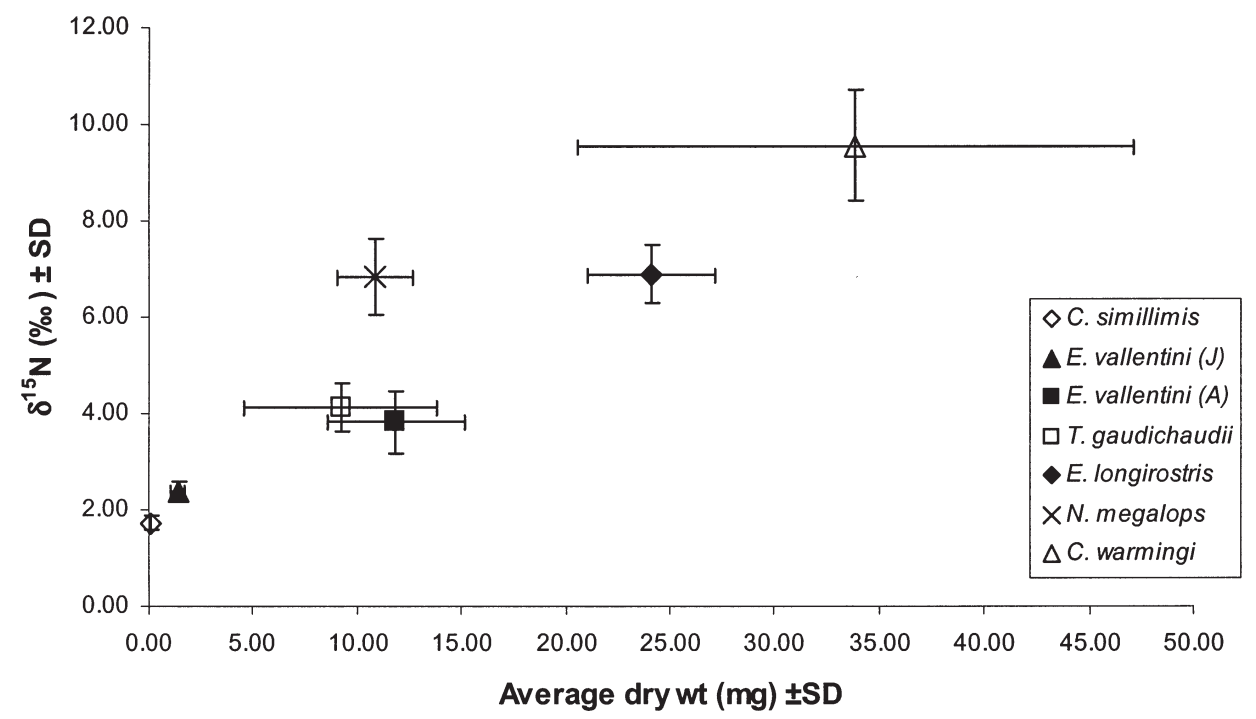

Fig. 2. Dry weight and stable nitrogen isotope ratios with standard deviation (SD) bars $(\mathrm{A}=$ adult; $\mathrm{J}=$ juvenile) 


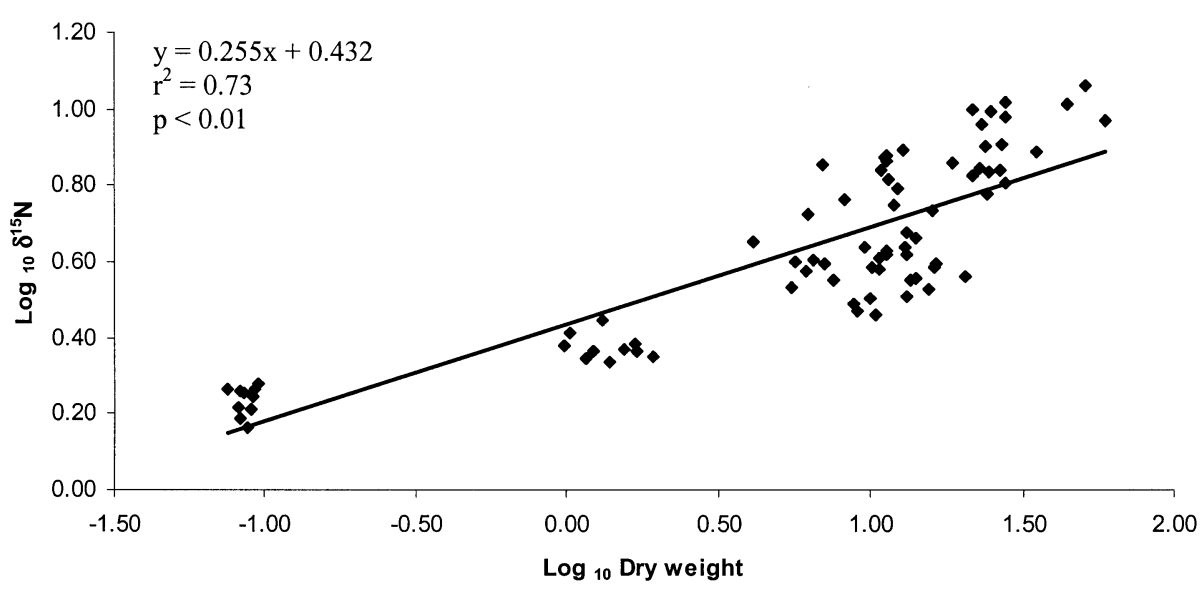

Fig. 3. Relationship between stable nitrogen isotope ratios and dry weight

mean values between 9.01 and $14.00 \mathrm{mg}$, while $E$. longirostris was significantly larger (mean of $24.9 \pm$ $3.36 \mathrm{mg})$. Ceratoscopelus warmingi was the largest group with a mean dry weight of $33.89 \pm 13.27 \mathrm{mg}$.

\section{DISCUSSION}

While feeding ecology studies of euphausiids have been carried out in the high Antarctic region, they are lacking in other regions of the Southern Ocean. The only data of this nature available in the vicinity of the Prince Edward Islands is during austral autumn; therefore, seasonal variation within the system has not been addressed. In addition, the isotope results presented in this study may not be directly compared to studies where samples were not treated with formaldehyde. Although $\delta^{15} \mathrm{~N}$ signatures could be affected by $<1 \%$ (Mullin et al. 1984), the results of this comparative study clearly show differences in relative trophic positions within the system. Because all specimens (except fish) were selected from the same samples and all feed in the well-mixed surface waters, the assumption that these specimens occupy the same isotopic environment may be considered valid.

Evidence presented in this study, from both techniques employed, showed that Euphausia vallentini juveniles were found to be herbivorous. E. vallentini adults may be considered omnivorous, but the contribution of carnivory to the diet was difficult to determine. The high phytoplankton contribution, and relatively low mesozooplankton components of the gut content analysis, suggested a herbivorous diet. However, the stable nitrogen isotope results indicate a high degree of omnivory and suggest that there was a large heterotrophic contribution to the diet of E. vallentini adults. Irrespective of the degree of carnivory, the iso- tope results show a dietary shift with an increase in size of E. vallentini, as has been observed for other euphausiid species (Mauchline \& Fisher 1969).

Themisto gaudichaudi, which has been described as an opportunistic predator (Pakhomov \& Perissinotto 1996), had a $\delta^{15} \mathrm{~N} 2.41 \%$ higher than that of Calanus simillimus. As discussed earlier, Minagawa \& Wada (1984) reported an average stepwise increase of $3.4 \pm$ $1.1 \%$ between trophic levels. Considering this, the isotope value observed for T. gaudichaudi was lower than expected. To offer a possible explanation for this, pigments from phytoplankton have been observed in the stomachs of T. gaudichaudi (Pakhomov \& Perissinotto 1996) and other hyperiid amphipods (T. japonica; Sugisaki et al. 1991). It is unlikely that the phytoplankton was consumed directly by the amphipod, and pigments must therefore be considered secondary in origin. Irrespective of the origin of the material, the isotope signature obtained here suggests that phytoplankton may be assimilated into the organism as the isotope ratio reflects that of an omnivore.

Gut content analysis of Euphausia longirostris showed that this species consumed large amounts of both phytoplankton and metazoan prey. However, the stable nitrogen isotope analysis indicated that this species was carnivorous and occupied a trophic position above that of E. vallentini adults. The gut content results for Nematoscelis megalops showed relatively high phytoplankton and metazoan contributions to the diet, suggesting an omnivorous feeding habit for this species. However, the trophic position, as identified by isotope ratios, was shared with that of E. longirostris and clearly indicated a high heterotrophic carbon component to the diet. This study has provided an opportunity for the direct comparison of these 2 techniques on the same individuals. It has clearly shown that, while the results of gut content analysis may provide infor- 
mation on items consumed, the realistic trophic position of an organism may be misidentified by using this technique alone.

Lastly, although several authors have used the theory of stepwise increases to delineate trophic position (e.g. Wada et al. 1991), it is well documented that relative enrichment between predatory zooplankton and their prey will depend on the extent of omnivory by the organism (Dunton et al. 1989, Kling et al. 1992, Jennings et al. 1997, France et al. 1998). France et al. (1998) suggested that because of this, trophic continua are more appropriate than discreet trophic levels. As only 6 species (or 7 groups) have been considered in this study, it is difficult to assess whether each group represents a discreet trophic level, or whether they are isolated points on a continuum, resulting from varying degrees of omnivory. Body size has been presented as an important factor in determining trophic position (France et al. 1998). The results of this study support this finding as $\delta^{15} \mathrm{~N}$ was positively correlated with dry weight (log transformed data; $\mathrm{r}^{2}=0.73$ ). There was however an interesting anomaly. The dry weights of Euphausia vallentini adults, Themisto gaudichaudi and Nematoscelis megalops were closely grouped $(\mathrm{p}<$ $0.05)$, yet $N$. megalops had a significantly higher mean $\delta^{15} \mathrm{~N}$ value $(\mathrm{p}<0.05)$. This trophic position was shared with that of the larger euphausiid, E. longirostris. The extended second appendage of $N$. megalops is considered to be a morphological adaptation, which assists in predation (Mauchline 1967). Therefore, while body size is important in determining the trophic position that an organism occupies, morphological adaptations cannot be overlooked.

Euphausiids have been shown to be an important part of the Prince Edward Island ecosystem, forming a principal component of the diet of many of the predators in the vicinity of the islands (Brown \& Klages 1987, Ridoux 1988, Brown et al. 1990, Cooper \& Brown 1990, Cooper et al. 1992, Bost et al. 1994a,b). The flow of carbon through the food web in the Southern Ocean has recently received much attention and elucidating the trophic interactions at species level is of great importance. While the findings of this study are comparative in nature and limited in that they only represent a single season (austral autumn), they nonetheless provide useful results. The findings support those in the literature and show that Euphausia vallentini juveniles are herbivorous and Nematoscelis megalops adults are carnivorous. However, adults of E. vallentini and E. longirostris appear to have higher contributions of heterotrophic carbon to their diets than had been assumed, and may occupy higher trophic positions than initially predicted. This study also highlighted the importance of using a combination of techniques, as a single tech- nique may often not reflect the true trophic position of an organism.

Acknowledgements. The authors would like to thank the Department of Environmental Affairs and Tourism and the National Foundation for Research in South Africa for funding, Rhodes University and the University of Cape Town for use of facilities, the captain and crew of the MV 'SA Agulhas' for assistance with collection of samples and special thanks to Dr Lee-Thorp for assistance with the isotope analysis.

\section{LITERATURE CITED}

Baker A de C, Boden BP, Brinton E (1990) A practical guide to the euphausiids of the world. British Museum (Natural History), London

Boden BP, Reid FMH (1989) Marine plankton diatoms between Cape Town and the Prince Edward Islands (SW Indian Ocean). S Afr J Antarct Res 19(2):2-49

Bost CA, Koubbi P, Genevois F, Ruchon L, Ridoux V (1994a) Gentoo penguin Pygoscelis papua diet as an indicator of planktonic availability in the Kerguelen Islands. Pol Biol 14:147-153

Bost CA, Puetz K, Lage J (1994b) Maximum diving depth and diving patterns of the gentoo penguin Pygoscelis papua at the Crozet Islands. Mar Ornithol 22(2):237-244

Brown CR, Klages NT (1987) Seasonal and annual variation in diets of Macoroni (Eudyptes chrysolophus chrysolophus) and Southern Rockhopper (E. chrysocome chrysocome) penguins at sub-Antarctic Marion Island. J Zool 212:7-28

Brown CR, Klages NT, Adams NJ (1990) Short and mediumterm variation in the diets of penguins at Marion Island. $\mathrm{S}$ Afr J Antarct Res 20:13-20

Cooper J, Brown CR (1990) Ornithological research at the sub-Antarctic Prince Edward Islands: a review of achievements. S Afr J Antarct Res 20:13-20

Cooper J, Fourie A, Klages NTW (1992) Diet of the Whitechinned Petrel Procellaria aequinoctialis at sub-antarctic Marion Island. Mar Ornithol 20(1/2):17-24

Dunton KH, Saupe SM, Golikov AN, Schell DM, Schonberg SV (1989) Trophic relationships and isotopic gradients among arctic and sub-Arctic marine fauna. Mar Ecol Prog Ser 56:89-97

France R, Chandler M, Peters R (1998) Mapping trophic continua of benthic foodwebs: body size $-\delta^{15} \mathrm{~N}$ relationships. Mar Ecol Prog Ser 174:301-306

Gu B, Schell DM, Alexander V (1994) Stable carbon and nitrogen isotopic analysis of the plankton food web in a subarctic lake. Can J Fish Aquat Sci 51:1338-1344

Hobson KA (1993) Trophic relationships among high arctic seabirds: insights from tissue-dependent stable-isotope models. Mar Ecol Prog Ser 95:7-18

Hobson KA, Welch HE (1995) Cannibalism and trophic structure in a high Arctic lake: insights from stable-isotope analysis. Can J Fish Aquat Sci 52:1195-1201

Holmes ME (1996) Reconstruction of surface ocean nitrate utilization in the southeast Atlantic ocean based on stable nitrogen isotopes. Ber Fachber Geowiss Univ Bremen 83: $4-8$

Hopkins TL (1985) Food web of an Antarctic midwater ecosystem. Mar Biol 89:197-212

Hopkins TL, Torres JJ (1989) Midwater food web in the vicinity of a marginal ice zone in the western Weddell Sea. Deep-Sea Res 36(4):543-560 
Hopkins TL, Lancraft TM, Torres JJ, Donnelly J (1993) Community structure and trophic ecology of zooplankton in the Scotia Sea marginal ice zone in winter (1988). Deep-Sea Res 40(1):81-105

Jennings S, Renones O, Morales-Nin B, Polunin NVC, Moranta J, Coll J (1997) Spatial variation in the ${ }^{15} \mathrm{~N}$ and ${ }^{13} \mathrm{C}$ stable isotope composition of plants, invertebrates and fishes on Mediterranean reefs: implications for the study of trophic pathways. Mar Ecol Prog Ser 146:109-116

Kirkwood JM (1982) A guide to the Euphausiacea of the Southern Ocean. Australian National Antarctic Research Expeditions Research Notes \#1. Department of Science and Technology, Australian Antarctic Division, Hobart, p 1-45

Kling GW, Fry B, O'Brien WJ (1992) Stable isotopes and planktonic trophic structure in arctic lakes. Ecology 73(2): 561-566

Mauchline J (1967) Feeding appendages of the Euphausiacea (Crustacea). J Zool 153:1-43

Mauchline J (1980) The biology of mysids and euphausiids. Adv Mar Biol 18:1-681

Mauchline J, Fisher LR (1969) The biology of euphausiids. Adv Mar Biol 7:1-454

Minagawa M, Wada E (1984) Stepwise enrichment of ${ }^{15} \mathrm{~N}$ along food chains: Further evidence and the relation between $\delta^{15} \mathrm{~N}$ and animal age. Geochim Cosmochim Acta 48:1135-1140

Mullin MM, Rau GH, Eppley RW (1984) Stable nitrogen isotopes in zooplankton: Some geographic and temporal variations in the North Pacific. Limnol Oceanogr 29(6): 1267-1273

Pakhomov EA, Perissinotto R (1996) Trophodynamics of the

Editorial responsibility: Otto Kinne (Editor),

Oldendorf/Luhe, Germany hyperiid amphipod Themisto gaudichaudi in the South Georgia region during late austral summer. Mar Ecol Prog Ser 134:91-100

Priddle J, Fryxell G (1985) Handbook of the common plankton diatoms of the Southern Ocean. Centrales except the genus Thalassiosira. British Antarctic Survey Natural Environment Research Council. University Press, Cambridge

Ridoux V (1988) Subantarctic krill, Euphausia vallentini Stebbing, preyed upon by penguins around Crozet Islands (southern Indian Ocean): population structure and annual cycle. J Plankton Res 10(4):675-690

Sugisaki H, Terazaki M, Wada E, Nemoto T (1991) Feeding habits of a pelagic amphipod, Themisto japonica. Mar Biol 109:241-244

Tomas CR (ed) (1996) Identifying marine diatoms and dinoflagellates. Academic Press Inc, San Diego, CA

Thomas CJ, Cahoon LB (1993) Stable isotope analyses differentiate between different trophic pathways supporting rocky-reef fishes. Mar Ecol Prog Ser 95:19-24

Tiezen LL, Boutton TW, Tesdahl KG, Slade NA (1983) Fractionation and turnover of stable carbon isotopes in animal tissues: Implications for $\delta^{13} \mathrm{C}$ analysis of diet. Oecologia 57: 32-37

Tirasin EM, Jørgensen T (1999) An evaluation of the precision of diet description. Mar Ecol Prog Ser 182:243-252

Wada E, Mizutani H, Minagawa (1991) The use of stable isotopes for food web analysis. Crit Rev Food Sci Nutrit 30(3): $361-371$

Zar JH (1984) Biostatistical analysis. Prentice-Hall, Englewood Cliffs, NJ

Submitted: August 31, 2000; Accepted: April 19, 2001

Proofs received from author(s): July 10, 2001 